\title{
Irfani
}

ISSN 1907-0969 E ISSN 2442-8272

Volume 15 Nomor 1 Juni 2019

Halaman 145-168

http://journal.iaingorontalo.ac.id/index.php/ir

\section{PENGARUH TUNJANGAN KINERJA DAN MOTIVASI TERHADAP PRODUKTIVITAS KINERJA PEGAWAI IAIN SULTAN AMAI GORONTALO}

\author{
Lasiyanti $^{1}$ Siti Asiah T. Pido ${ }^{2}$ Arten H Mobonggi $^{3}$ \\ Institut Agama Islam Negeri (IAIN) Sultan Amai Gorontalo \\ Email: lasiyanti@iaingorontalo.ac.id
}

\begin{abstract}
ABSTRAK
Artikel ini bertujuan untuk mengetahui seberapa besar pengaruh tunjangan kinerja terhadap kinerja pegawai IAIN Sultan Amai Gorontalo dan berapa besar pengaruh motivasi terhadap kinerja pegawai IAIN Sultan Amai Gorontalo. Metode yang digunakan masuk dalam jenis penelitian kuantitatif dengan teknik sampling yang digunakan adalah proporsional Random sampling. Populasi dalam penelitian ini berjumlah 205 orang, sampel yang diteliti 67 orang. Pengumpulan data penulis menggunakan angket dan jenis analisis yang digunakan yaitu analisis Regresi Linear Berganda.Hasil penelitian dan pembahasan, menujukkan bahwa Tunjangan Kinerja dan Motivasi berpengaruh Terhadap Kinerja Pegawai setelah diuji menggunakan rumus Regresi sederhana masing-masing $\mathrm{Y}=57.266+0.345 \mathrm{X}_{1}$ dan $Y=15.821+0.991 X_{2}$. Hal ini membuktikan bahwa tunjangan Kinerja dan Motivasi memiliki pengaruh yang signifikan terhadap Kinerja Pegawai serta mengakibatkan peningkatan masing-masing sebesar 0.345 dan 0.991 pada konstanta 57.266 dan 15.821.hal ini juga dibuktikan dengan pengujian Hipotesis dimana uji parsial masing masing $t_{\text {hitung }}>t_{\text {tabel }}$ yaitu $X_{1}(3.117>1,980)$ dan $X_{2}$ (11.982 > 1,980). Maka $\mathrm{H}_{0}$ ditolak. Demikian juga dengan menggunakan rumurs analisis Regresi berganda $Y=a+b_{1} X_{1+} b_{2} X_{2}=17.754+0,126 X_{1}+0,886 X_{2}$, maka pengujian hipotesis secara bersama-sama di dapat $F_{\text {hitung }}>T_{\text {tabel }}$ atau $117.453>1,980$, maka $\mathrm{H}_{0}$ di tolak dan $\mathrm{Ha}$ di terima. Faktor Tunjangan Kinerja dan Motivasi memberikan sumbangan efektif sebesar 78,6\%, dapat diartikan Kinerja Pegawai dipengaruhi oleh Tunjangan Kinerja dan Motivasi sedangkan $21,4 \%$ merupakan pengaruh dari luar variabel yang tidak dimasukan dalam model penelitian ini.
\end{abstract}

Kata Kunci: Tunjangan Kinerja, Motivasi Dan Kinerja Pegawai 
Volume 15 Nomor 1 Juni 2019

Halaman 145-168

http://journal.iaingorontalo.ac.id/index.php/ir

\section{PENDAHULUAN}

Instansi terbentuk dari suatu kolektif berupa unit organisasi pemerintahan yang menjalankan tugas dan fungsinya sesuai dengan ketentuan yang berlaku. Instansi dibuat berdasarkan berbagai visi untuk kepentingan manusia. Keberhasilan instansi sangat ditentukan oleh kualitas dari sumber daya manusia (SDM) yang bekerja di dalamnya. Sumber daya manusia yang merupakan aset instansi paling unik, paling rentan, paling murni dan sukar untuk di prediksi. Sumber daya manusia juga menjalankan aktifitas instansi secara dinamis dan memiliki kemampuan untuk terus berkembang.

Pegawai Negeri Sipil dalam organisasi dikenal dengan nama Korps Pegawai Republik Indonesia (KORPRI). Tujuan Korps Pegawai Republik Indonesia (KORPRI). Adalah memperjuangkan kemandirian dan kesejahteraan Pegawai Negeri Sipil. Terwujudnya KORPRI sebagai organisasi yang netral, mandiri, kuat, profesional dan terdepan dalam menjaga persatuan dan kesatuan bangsa, mensejahterakan anggota, masyarakat, dan melindungi kepentingan para anggota agar lebih profesional di dalam membangun satu pemerintahan yang baik.

Menurut Undang-Undang Aparatur Sipil Negara No.5 tahun 2015 disebutkan bahwa Tunjangan kinerja dibayarkan sesuai pencapaian kinerja. Pemberian tunjangan kinerja harus seiring dengan peningkatan kinerja pegawai. Karenanya, seluruh PNS harus meningkatkan integritas, disiplin, prestasi kerja (kinerja), kerjasama diantara para pegawai, serta meningkatkan komitmen ${ }^{1}$. Tunjangan kinerja bersifat fluktuatif tergantung grade dan kinerja pegawai yang bersangkutan. Hal itu sesuai dengan pendapat Simamora yang menyatakan bahwa prinsip kompensasi dilakukan sesuai prestasi dan tanggung jawab pegawai tersebut. Dari perspektif teoritis kompensasi berbasis kinerja merupakan gagasan yang inovatif karena sistem ini memungkinkan organisasi mendorong tingkat rata-rata motivasi kerja individu, meningkatkan pencapaian yang berorientasi individu dan mempertahankan penilaian yang tinggi bagi pegawai yang memiliki kinerja tinggi ${ }^{2}$

Pemberian tunjangan kinerja pada PNS dinilai sebagai motivasi yang meningkatkan dapat kinerja para pegawai. Motivasi kerja pegawai negeri sipil yang dominan dalam mencapai tujuan suatu instansi perlu mendapat perhatian

${ }^{1}$ Undang-Undang Aparatur Sipil Negara No.5 tahun 2015

${ }^{2}$ Yusnia Hanifah Jurnal Bisnis dan Manajemen Vol. 11, No. 2 Mei 2017 , Pengaruh Tunjangan Kinerja Terhadap Motivasi Kerja, Disiplin Kerja Dan Kinerja Pegawai Balai Pengelolaan Daerah Aliran Sungai Di Jawa Timur Hal. 187 - 193 


\section{Irfani}

ISSN 1907-0969 E ISSN 2442-8272

Volume 15 Nomor 1 Juni 2019

Halaman 145-168

http://journal.iaingorontalo.ac.id/index.php/ir

secara khusus. Peranan motivasi kinerja PNS pada suatu instansi dapat juga menunjang pemenuhan kebutuhan berprestasi sangat besar, dengan keterangan lain motivasi mempunyai hubungan yang positif terhadap prestasi kerja yang lebih baik dan sebaliknya.

Prestasi kerja pegawai dapat dilihat dari seberapa besar motivasi pegawai dalam melaksanakan setiap tugas atau pekerjaan yang menjadi tanggung jawabnya sangat tergantung pada keseimbangan antara produktifitas kerja dan kesejahteraan yang diterimanya. Pimpinan instansi atau unit kerja memiliki kewajiban untuk selalu memberi motivasi agar pegawainya lebih meningkatkan kinerjanya, melakukan kerja sama dan saling memahami tugas serta fungsi dari setiap unit kerja dapat berjalan dengan baik sesuai yang diharapkan. Faktor-faktor eksternal pada setiap pegawai dapat diketahui atau dipahami oleh pimpinan dengan mempengaruhi, memberi motivasi, member arahan, mudah berkomunikasi dengan pegawai dan dengan memilih berbagai sarana atau alat yang sesuai dengan pegawai tersebut, akan sangat mempengaruhi efektivitas pimpinan.

Penilaian prestasi kerja PNS dilakukan oleh pejabat penilai terhadap Sasaran Kerja Pegawai (SKP) dan perilaku kerja PNS. Dengan dilakukannya penilaian prestasi kerja akan dapat mewujudkan keadilan dalam pemberian benefit, mengingat seorang PNS yang berprestasi akan mendapatkan benefit yang lebih baik dibandingkan PNS-PNS lainnnya.Selanjutnya agar dapat menghasilkan penilaian kinerja yang valid dan readible, maka perlu adanya instrumen pengukuran kinerja sebagai alat yang dipakai untuk mengukur kinerja individu seorang pegawai ${ }^{3}$.

Seperti halnya terjadi pada Institut Agama Islam (IAIN) Sultan Amai Gorontalo yang dilatarbelakangi oleh adanya dorongan dan keinginan luhur dari para tokoh agama, tokoh masyarakat, dan Pemerintah Daerah Gorontalo yang memiliki komitmen keislaman yang tinggi. Kampus IAIN Sultan Amai Gorontalo memiliki Pegawai Negeri Sipil 205 orang. PNS yang memiliki jabatan fungsional dan struktural serta yang menerima tunjangan kinerja juga berjumlah 205 orang. Pemberian tunjangan kinerja dan cara penilaian kinerja untuk Pegawai Negeri Sipil dilingkungan IAIN Sultan Amai Gorontalo dilakukan sesuai dengan peraturan pemerintah No 107 Tahun 2013. Sesuai informasi yang diberikan oleh

${ }^{3}$ Liza Hardani (Balai Karantina Pertanian Kelas I Banjarmasin) Ahmad Alim Bachri (Universitas Lambung Mangkurat Banjarmasin) Dahniar (Universitas Lambung Mangkurat Banjarmasin Jurnal Wawasan Manajemen, Vol. 4, Nomor 1, Februari 2016 


\section{Irfani}

ISSN 1907-0969 E ISSN 2442-8272

Volume 15 Nomor 1 Juni 2019

Halaman 145-168

http://journal.iaingorontalo.ac.id/index.php/ir

bagian kepegawaian IAIN Sultan Amai Gorontalo bahwa Pemberian Tunjangan kinerja Pegawai Negeri Sipil dilakukan dengan berdasarkan tingkat kehadiran pegawai, laporan kegiatan harian (LKH) setiap bulannya dan system kinerja pegawai (SKP) setiap tahunnya. Untuk indicator jumlah pekerjaan, kualitas pekerjaan dan kemampuan kerja sama itu belum dilakukan penilaian. Dalam melaksanakan pekerjaan pegawai administrasi dan dosen di IAIN Sultan Amai Gorontalo dalam pengamatan peneliti masih terdapat kekurangan. Dosen dan pegawai administrasi yang sering datang terlambat dari ketentuan waktu yang telah ditetapkan, keterlambatan dalam pemasukan Laporan kerja harian (LKH) yang tidak tepat waktu juga mempengaruhi penerimaan tunjangan kinerja (TUKIN), kurangnya kesadaran dari pegawai untuk bekerja lebih optimal dalam melakukan pekerjaan, seringkali pegawai melanggar disiplin dalam pekerjaan sehingga oleh atasan diberi sangsi akan tetapi sangsi yang diberikan tidak memberikan efek jera.

berdasarkan latar belakang diatas, maka permasalahn penelitian ini dapat diidentifkasi sebagai berikut :

1. Pegawai administrasi dan dosen sering datang terlambat dari waktu yang telah ditentukan

2. Ketidaktepatan waktu dalam pemasukan Laporan Kerja Harian (LKH)

3. Pegawai melanggar disiplin dalam pekerjaan sehingga oleh atasan diberi sangsi akan tetapi sangsi yang diberikan tidak memberikan efek jera.

Kurang patuhnya pegawai kepada atasan, hal ini bisa disebabkan oleh pegawai merasa lebih tua atau atasan dianggap kurang berpengalaman dalam melakukan tugas pokok dan fungsinya

\section{Tunjangan Kinerja}

Tunjangan kinerja yang berbasis kinerja adalah merupakan suatu system pembayaran yang berkaitan dengan imbalan atau reward dengan performance atau prestasi kerja. Pemahamannya adalah seseorang yang berkinerja bagus maka akan memperoleh reward yang lebih tinggi demikian pula sebaliknya. Artinya, semakin tinggi kinerja yang diraih seorang pegawai maka semakin besar pula imbalan yang diterima.

Peraturan Menteri Agama nomor 29 tahun 2016 tentang pedoman pelaksanaan Pemberian tunjangan kinerja bagi pegawai negeri sipil dilingkungan kementerian Agama menjelaskan Tunjangan Kinerja adalah tunjangan yang diberikan kepada pegawai negeri yang merupakan fungsi dari keberhasilan pelaksanaan reformasi birokrasi dan didasarkan pada capaian kinerja pegawai 


\section{Irfani}

ISSN 1907-0969 E ISSN 2442-8272

Volume 15 Nomor 1 Juni 2019

Halaman 145-168

http://journal.iaingorontalo.ac.id/index.php/ir

negeri tersebut yang sejalan dengan capaian kinerja organisasi yang pegawai negeri tersebut bekerja ${ }^{4}$. Adapun komponen penentu besaran tunjangan kinerja yang berdasarkan tiga komponen yaitu :

a. Tingkat pencapaian kinerja pegawai

b. Tingkat kehadiran menurut hari dan jam kerja

c. Ketaatan pada kode etik dan disiplin pegawai

Tunjangan kinerja diberikan dengan jumlah yang berbeda di setiap masingmasing unit kementerian. Diberikannya tunjangan kinerja adalah sebagai remunerasi reformasi birokrasi yang telah dilaksanakan oleh masing- masing unit dengan memperhatikan dan mempertimbangkan persetujuan dari menteri.

Penilaian tunjangan kinerja pegawai dapat meningkat ataupun menurun tergantung pada kinerja pegawai itu sendiri. Antara tunjangan kinerja dan kinerja pegawai merupakan dua unsur yang saling berhubungan. Dengan kata lain, tunjangan kinerja adalah proses pemberian imbalan yang diberikan sesuai dengan hasil kerja dari pegawai itu sendiri. Pemberian tunjangan diberikan secara adil dan layak sesuai dengan tupoksi dan tanggung jawab untuk memacu produktivitas serta menjamin kesejahteraan pegawainya. Pegawai yang telah menenima tunjangan harus memiliki kinerja yang dapat diukur melalui penerapan kerja pegawai (SKP).

Tunjangan kinerja pegawai diberikan berdasarkan rekapan kehadiran pegawai setiap bulannya. Hal ini berdampak pada kedisiplinan pegawai secara keseluruhan. Kedisiplinan merupakan salah satu fungsi operatif dalam manajemen sumber daya manusia yang pokok. Karena semakin baik baik tingkat disiplin seorang pegawai maka semakin tinggi pulan prestasi yang dicapai.

\section{Motivasi}

Menurut Mc. Donald dalam Sardiman motivasi adalah suatu perubahan energi dalam diri seseorang yang ditandai dengan timbulnya feeling atau perasaan yang didahului dengan tanggapan terhadap adanya tujuan. ${ }^{5}$ Dari pengertian yang dikemukakan Mc. Donald mengandung 3 elemen penting yaitu :

\footnotetext{
${ }^{4}$ Peraturan Menteri Agama nomor 29 tahun 2016 tentang pedoman pelaksanaan Pemberian tunjangan kinerja bagi pegawai negeri sipil

${ }^{5}$ Sardiman, Interaksi Dan Motivasi Belajar,(Jakarta: Rajawali Pers, 2011) h. 73
} 


\section{Irfani}

ISSN 1907-0969 E ISSN 2442-8272

Volume 15 Nomor 1 Juni 2019

Halaman 145-168

http://journal.iaingorontalo.ac.id/index.php/ir

1. Motivasi diawali terjadinya perubahan energy pada diri seseorang

2. Motivasi ditandai dengan munculnya rasa feeling, afeksi seseorang dalam hal ini relevan dengan persoalan kejiwaan, afeksi dan emosi yang dapat menentukan prilaku manusia.

3. Motivasi akan dirangsang karena adanya suatu tujuan. Dalam hal ini merupakan respon dari aksi yaitu tujuan. ${ }^{6}$

Dengan ketiga elemen diatas maka dapat dikatakan bahwa motivasi sebagai sesuatu yang kompleks. Motivasi akan menyebabkan terjadinya suatu perubahan energy yang ada dalam diri individu. Motivasi sebagai adanya dorongan dan usaha dalam memuaskan kebutuhan atau suatu tujuan. Motivasi ibarat suatu kerelaan untuk berupaya semaksimal mungkin dalam proses pencapaian tujuan yang mempengaruhi kemampuan usaha untuk memuaskan beberapa kebutuhan individu.

Motivasi adalah merupakan suatu faktor pendorong yang mengubah energy dalam diri seseorang dalam bentuk aktivitas nyata untuk mencapai suatu tujuan tertentu. Motivasi merupakan suatu dorongan dari dalam individu untuk melakukan suatu tindakan dengan cara tertentu sesuai dengan tujuan yang direncanakan. ${ }^{7}$

Teori motivasi kerja adalah suatu rangsangan bagi pegawai dalam bekerja menjalankan tugasnya. Motivasi yang baik pasti pegawai akan merasa senang dan semangat dalam bekerja. Sehingganya, mengakibatkan pertumbuhan dan perkembangan yang signifikan terhadap instansi. Untuk Menumbuhkan motivasi diri dalam bekerja, maka perlu diawali dengan adanya niat kemudian dengan mensyukuri pekerjaan. Motivasi bukan dilaksanakan dari atasan saja melainkan dari diri sendiri dimana motivasi sebagai suatu keadaan dalam diri pribadi yang berkeinginan untuk melaksanakan kegiatan tertentu agar tujuan yang diharapkan tercapai.

Teori motivasi menurut Hezberg dalam Hasibuan mengemukakan bahwa teori motivasi yang ideal yang mampu merangsang usaha ialah suatu peluang dalam mengembangkan kemampuan. Dimana Hezberg mengatakan bahwa seseorang yang menjalankan pekerjaan dapat dipengaruhi oleh dua faktor yaitu

\footnotetext{
${ }^{6}$ Ibid.h.74

7 Kompri,Motivasi Pembelajaran Perspektif Guru Dan Siswa(Bandung:PT Remaja Rosdakarya Offset,2015)Cet.1 H.5
} 


\section{Irfani}

ISSN 1907-0969 E ISSN 2442-8272

Volume 15 Nomor 1 Juni 2019

Halaman 145-168

http://journal.iaingorontalo.ac.id/index.php/ir

faktor Hiegenis dan faktor motivasi atau dikenal dengan faktor satisfiers. Faktor motivasi (satisfiers) meliputi :

1) Prestasi (Achievment) : suatu prestasi kerja atau hasil kerja yang diraih seseorang dalam menjalankan tugas ats kecakapnnya, atas usahanya dan kesempatannya (Hasibuan 2014)

2) Pengakuan (Recognition) yakni : Besar atau kecilnya suatu pengakuan yang diberikan kepada pekerja atas hasil kerjanya (Siagian 2012)

3) Tanggung Jawab (Responsibillity) yaitu : besar atau kecilnya tanggungjawab yang dimiliki seorang pekerja

4) Pekerjaan itu sendiri (the work it self) yaitu : berat atau ringannya suatu tantangan yang dirasa oleh pekerja (Siagian 2012)

5) Pengembangan potensi individu ((The possibility of growth)) yaitu: besar atau kecilnya seorang tenaga kerja kemungkinan memiliki peluang untuk maju dalam pekerjaan. ${ }^{8}$

Menurut Sutrisno dalam jane cristin (2010) mengemukakan bahwa motivasi internal adalah dorongan yang ada dari dalam diri pribadi seseorang. Dimana motivasi internal sangat berperan penting dalam menciptakan prestasi kerja yang tinggi serta kinerja yang optimal secara terus menerus. Sedangkan motivasi eksternal adalah dorongan yang ada dari dalam diri seseorang yang dipengaruhi oleh faktor internal yang dikendalikan oleh manager seperti kenaikan pangkat, tanggung jawab dan penghargaan. ${ }^{9}$

\section{Kinerja Pegawai}

Pada hakikatnya dalam melakukan suatu pekerjaan yang di dasari atas pemberian motivasi dibutuhkan kesiapan mental dalam melaksanakan pekerjaan. Kinerja adalah bentuk hasil dari pekerjaan seorang karyawan atau pegawai dalam menjalankan tugas yang diembannya. Kinerja berhubungan erat dengan sumber daya manusia dimana prestasi kerja atau hasil kerja yang diperoleh persatuan periode waktu adalah tanggung jawabnya dalam suatu organisasi. Hasil kerja atau prestasi kerja yang dimaksud dapt berupa hasil kerja yang sifatnya kualitatif

\footnotetext{
${ }^{8}$ Maya Andriani, Kristiana Wididawati, Penerapan Motivasi Karyawan Menurut Teori Dua Faktor Frederick Harzberg Pada PT Aristika Kreasi Mandiri, Jurnal Administrasi Kantor Vol. 5 No 1 Juni 2017

9 Jane Christin, Djudi Mukzam, pengaruh Motivasi Internal dan kesternal Terhadap Kinerja Karyawan, (Studi Kasus Pada Karyawan PT Indomarco Prismatama Distribution Centre Bogor, Jurnal Administrasi Bisnis (JAB) Vol.50 No 5 September 2017
} 


\section{Irfani}

ISSN 1907-0969 E ISSN 2442-8272

Volume 15 Nomor 1 Juni 2019

Halaman 145-168

http://journal.iaingorontalo.ac.id/index.php/ir

maupun kuantitatif yang dicapai seorang pegawai dalam melaksanakan tugas sesuai dengan tanggung jawab yang diberikan.

Kinerja adalah hasil yang diperoleh oleh suatu organisasi baik organisasi tersebut bersifat profit oriented dan non profit oriented yang dihasilkan selama satu periode. Kinerja dalam arti tindakan yang menghasilkan hasil. Yang berarti pekerjaan yang dilakukan individu. Untuk itu kinerja menekankan pada suatu aktifitas kegiatan yang menghasilkan sesuai dengan tujuan telah direncanakan dan diterapkan. Kinerja adalah segala sesuatu yang berhubungan langsung dengan potensi yang ada dalam mengambil tanggung jawab atau kepemilikan menyeluruh. Kinerja merupakan salah satu sendi dalam setiap aktifitas seseorang sehingga aktifitas itu dapat membuahkan hasil yang positif. Baik buruknya kinerja tersebut tergantung pada besar kecilnya potensi yang ada pada diri seseorang. ${ }^{10}$

Suatu pekerjaan memiliki syarat-syarat tertentu untuk dilakukan dalam mencapai tujuan organisasi. Indikator untuk mengukur kinerja pegawai menurut Robbins (2006) ${ }^{11}$, yaitu :

1. Kualitas. Kualitas kerja dapat diukur dari prestasi kerja pegawai terhadap kualitas pekerjaan yang dihasilkan serta memiliki kemampuan dan ketrampilan karyawan.

2. Kuantitas. Kuantitas adalah jumlah pekerjaan yang dihasilkan oleh pegawai baik secara individu maupen kelompok

3. Ketepatan waktu. Merupakan tingkat keaktifan yang diselesaikan pada wal waktu yang dilihat dari sudut kordinasi dengan hasil output serta pemaksimalan waktu yang tersedia untuk aktivitas lain.

4. Efektifitas. Tingkat penggunaan sumber daya organisasi yang mencakup tenaga, anggaran, teknologi, bahan baku, dimaksimalkan dengan menaikan hasil dari setiap unit dalam pemanfaatan sumber daya.

5. Kemandirian. Tingkat kerja pegawai yang nantinya mampu menjalankan fungsi kerja serta komitmen kerjanya, yang merupakan tingkat dimana pegawai memiliki komitmen kerja dengan instansi serta tanggung jawab terhadap kantor.

\footnotetext{
${ }^{10}$ Tika, P. Budaya Organisasi Dan Peningkatan Kinerja Perusahaan. ( PT Bumi Aksara. Jakarta2006)h. 12

${ }^{11}$ Robbins Stephen P, Perilaku Organisasi (Jakarta :PT Indeks kelompok Gramedi,2006)h. 260
} 


\section{Irfani}

ISSN 1907-0969 E ISSN 2442-8272

Volume 15 Nomor 1 Juni 2019

Halaman 145-168

http://journal.iaingorontalo.ac.id/index.php/ir

Pada dasarnya hasil kerja seorang pegawai secara kualitas dan kuantitas dapat tercapai dalam menjalankan tugas dan tanggungjawab yang diberikan. Sesungguhnya, seorang pegawai dalam menjalankan pekerjaan tidakn akan bekerja sendiri tanpa ada dorongan serta perintah tugas yang diberikan oleh atasan atau pimpinan. ${ }^{12}$

Menyadari tugas pelayanan aparatur sipil Negara (ASN) merupakan faktor utama guna menunjang keberhasilan pelaksanaan penyelenggaraan pemerintahan dalam membangun kepercayaan masyarakat akan pelayanan yang dilakukan oleh pegawai pemerintah, pastinya seorang aparatur Negara seyogyanya selalu mengupayakan hal-hal yang berguna dalam menunjang keberhasilan penyelenggaraan pemerintahan.

Sebuah instansi pemerintahan merupakan suatu organisasi yang memberikan pelayanan terhadap masyarakat di tuntut untuk mampu menyesuaikan diri dengan lingkungan serta perkembangan yang selalu agar terus melakukan perubahan-perubahan. Akan tercapainya efektivitas organisasi ditentukan oleh kinerja dari pegawai-pegawai dalam melaksanakan tugas dan tanggung jawab yang di embannya. Pada instatnsi pemerintah berhasil tidaknya tujuan awal dari program kinerja dan kebijakan-kebijakan yang telah ditetapkan ditentukan oleh kinerja dari pegawai-pegawai itu sendiri. Kinerja merupakan tolak ukur terpenting dari kualitas organisasi.

Salah satu upaya pemerintah dalam peningkatan kesejahteraan pegawai adalah dengan menerapkan kebijakan tunjangan kinerja. Dimana, tunjangan kinerja adalah penghasilan diluar gaji yang diberikan kepada pegawai aktif berdasarkan kinerja dan kompetensinya. Instansi kementerian agama adalah merupakan instansi pemerintah yang menerapkan kebijakan tunjangan kinerja. Selain sebagai upaya peningkatan kesejahteraan, tunjangan kinerja yang diterapkan di kementerian agama juga adalah suatu upaya yang dilakukan untuk peningkatan kinerja pegawainya.

Proses pemberian tunjangan kinerja harus disesuaikan oleh seberapa besar kontribusi pegawai dalam menjalankan pekerjaannya. Penilaian kinerja merupakan bukti control dalam rangka memastikan bahwa tujuan organisasi dapat berjalan dengan baik, yang dibuktikan dengan kinerja yang dilakukan para pegawainya, penilaian kinerja merupakan bagian dari pengaturan terhadap sumber

${ }^{12}$ Pilatus Deikme, Motivasi Kerja Dan Budaya Organisasi Pengaruhnya Terhadap Kinerja Pegawai Bagian Keuangan Sekda Kabupaten Mimika provinsi Papua, Jurnal EMBA col.1 No 3 Juni 2013 


\section{Irfani}

ISSN 1907-0969 E ISSN 2442-8272

Volume 15 Nomor 1 Juni 2019

Halaman 145-168

http://journal.iaingorontalo.ac.id/index.php/ir

daya manusia, organisasi dengan penempatan kerja sesuai dengan kompetensi dan kualifikasinya. Aspek pemberian tunjangan kinerja dapat di klasifikan sebagai berikut : 1) Pengukuran Kinerja Pegawai Negeri Sipil, 2) Penilaian Kinerja Pegawai Negeri Sipil, 3) Disiplin Kinerja Pegawai Negeri Sipil

\section{Kerangka Pikir}

Bagan di bawah ini dapat menggambarkan bahwa Variabel Tunjangan Kinerja $\left(\boldsymbol{X}_{\boldsymbol{I}}\right)$ memiliki indikator : 1) Sasaran Kinerja Pegawai, yang meliputi pemberian tunjangan berdasarkan SKP, 2) Orientasi Pelayanan meliputi Pelayanan secara tepat waktu 3) Kerjasama. 4) Integritas. 5) Disiplin. Variabel Motivasi ( $\left.\boldsymbol{X}_{2}\right)$ indikatornya : 1) Prestasi (Achievment), 2) Pengakuan (Recognition), 3)Tanggung Jawab (Responsibillity), 4) Pekerjaan itu sendiri (the work it self), 5) Pengembangan potensi individu (The possibility of growth) Variabel Kinerja Pegawai (Y) indikatornya : 1) Kuantitas Kerja, 2) Kualitas kerja), 3) Ketepatan kerja.

\section{Hipotesis Penelitian}

Hipotesis merupakan penjelasan tentatif (sementara) yang perlu diverifikasi oleh fakta-fakta dilapangan yang kemudian dikumpulkan dan di analisis. $^{13}$

1. Hipotesis $X_{1}$ ke $Y$

Rumus $\mathrm{H}_{0}: \rho=0$ secara parsial tidak terdapat pengaruh antara Tunjangan

Kinerja dengan Kinerja Pegawai IAIN Sultan Amai Gorontalo

Rumus $\mathrm{H}_{\mathrm{a}}: \rho \neq 0$ secara parsial terdapat pengaruh antara Tunjangan Kinerja dengan Kinerja Pegawai IAIN Sultan Amai Gorontalo

2. Hipotesis $X_{2}$ ke $Y$

Rumus $\mathrm{H}_{0}: \rho=0$ secara parsial tidak terdapat pengaruh antara Motivasi dengan Kinerja Pegawai IAIN Sultan Amai Gorontalo

Rumus $\mathrm{H}_{\mathrm{a}}: \rho \neq 0$ secara parsial terdapat pengaruh antara Motivasi dengan Kinerja Pegawai IAIN Sultan Amai Gorontalo

${ }^{13}$ Uhar Suharputra, Metode Penelitian Kuantiitatif,Kualitatif dan tindakan (Bandung: PT Refika Aditama,2012) h. 63 


\section{Irfani}

ISSN 1907-0969 E ISSN 2442-8272

Volume 15 Nomor 1 Juni 2019

Halaman 145-168

http://journal.iaingorontalo.ac.id/index.php/ir

3. Hipotesis $X_{I}$ dan $X_{2}$ ke $Y$

Rumus $\mathrm{H}_{0}: \rho=0$ secara simultan tidak terdapat pengaruh antara Tunjangan Kinerja dan Motivasi terhadap Kinerja Pegawai IAIN Sultan Amai Gorontalo

Rumus $\mathrm{H}_{\mathrm{a}}: \rho \neq 0$ secara simultan terdapat pengaruh antara Tunjangan Kinerja dan Motivasi terhadap Kinerja Pegawai IAIN Sultan Amai Gorontalo

Metodologi Penelitian

Jenis pendekatan yang digunakan dalam penelitian ini adalah penelitian kuantitatif. Populasi dalam penelitian ini adalah seluruh pegawai negeri sipil yang menerima tunjangan kinerja sebanyak 205 orang di Institut Agama Islam Negeri Gorontalo (IAIN) Sultan Amai Gorontalo. Pegawai Negeri Sipil IAIN Sultan Amai Gorontalo yang mendapatkan TUKIN sebagai berikut : Pegawai Struktural

sebanyak 59 orang dan Dosen sebanyak 146 orang. Teknik pengambilan sampel pada penelitian ini yakni menggunakan teknik proporsional Random sampling.

Penentuan Sampel pada dasarnya tidak ada yang mutlak untuk menentukan berapa persen sampel dari populasi yang akan diambil. Untuk menentukan sampel dari suatu populasi sebagai berikut ${ }^{14}$ :

$$
n_{i}=\frac{N_{i}}{N} \cdot n
$$

\section{Dimana :}

$\mathrm{n}_{\mathrm{i}}=$ Jumlah Sampel Menurut stratum

$\mathrm{n}$ = Jumlah sampel seluruhnya

$\mathrm{N}_{\mathrm{i}}=$ Jumlah sampel menurut stratum

$\mathrm{N}=$ jumlah populasi seluruhnya

Dari keterangan diatas maka dapat diperoleh sampel sebagai berikut:

$$
n_{i}=\frac{N_{i}}{N} \cdot n
$$

Penyelesaiannya:

${ }^{14}$ Herson Anwar, Lian G. Otaya, Statistika Pendidikan Teori dan Aplikasi (Gorontalo :Sultan Amai Pres,2015) h. 71 


\section{Irfani}

ISSN 1907-0969 E ISSN 2442-8272

Volume 15 Nomor 1 Juni 2019

Halaman 145-168

http://journal.iaingorontalo.ac.id/index.php/ir

$$
n=\frac{205}{(205) \cdot(0,10)^{2}+1}=\frac{205}{(205) \cdot(0,1)^{2}+1}=\frac{205}{3 \cdot 05}=67,21
$$

Sampel penelitian 67,2 (dibulatkan menjadi 67 pegawai), kemudian untuk sampel berstrata menggunakan rumus : $\mathrm{n}_{\mathrm{i}}=\left(\mathrm{N}_{\mathrm{i}}: \mathrm{N}\right) \cdot \mathrm{n}$

Pegawai Struktural $=59: 205 \times 67=19$ orang

Dosen $\quad=\underline{146: 205 \times 67=48 \text { orang }}$

Dalam penelitian ini terdapat 3 (tiga) variabel penelitian, variabel pertama adalah tunjangan Kinerja, variabel kedua Motivasi, yang bersifat independen yaitu variabel yang mempengaruhi dan penyebab terjadinya perubahan. Variabel ketiga Kinerja Pegawai yang bersifat Dependen (Terikat) yaitu variabel yang dipengaruhi.

Pengumpulan data penulisan menggunakan angket dan jenis analisis yang digunakan adalah analisis linear sederhana dan analisis regresi berganda. Model persamaan regresi berganda dalam penelitian ini dengan rumus sebagai berikut :

$$
\mathbf{Y}=\mathbf{a}+\mathbf{b}_{1} \mathbf{X}_{1}+\mathbf{b}_{2} \mathbf{X}_{2}
$$

$\mathrm{Y}=$ Subyek dalam variabel dependen yang diprediksi $\mathrm{X} 1$ dan $\mathrm{X} 2$ variabel Independen

$\mathrm{a}=$ Harga $\mathrm{Y}$ ketika harga $\mathrm{X}=0$ (harga konstanta)

$\mathrm{b}=$ Angka arah atau koefisien regresi, yang menunjukan angka peningkatan ataupun penurunan variabel dependen yang didasarkan pada perubahan variabel independen. Bila (+) arah garis naik dan bila (-) arah garis turun.

\section{Uji Koefisien regresi secara bersama - sama (Uji F)}

Uji ini digunakan untuk mengetahui apakah variabel independen $\left(\mathrm{X}_{1}\right.$ dan $\mathrm{X}_{2}$ ) secara bersama - sama berpengaruh secara signifikan terhadap variabel dependen (Y) atau untuk mengetahui apakah model regresi dapat digunakan untuk memprediksi variabel dependen atau tidak. Misalnya populasi sebanyak 205 pegawai dan sampel yang diambil sebanyak 67 pegawai. Apakah pengaruh yang terjadi atau kesimpulan yang diperoleh berlaku untuk populasi yang berjumlah 205 pegawai.

Uji koefisien regresi dari variabel $\mathrm{X}_{1}$ (Tunjangan Kinerja) Variabel $\mathrm{X}_{2}$ (Motivasi) terhadap Variabel Y (Kinerja Pegawai) sebagai berikut : 


\section{Irfani}

ISSN 1907-0969 E ISSN 2442-8272

Volume 15 Nomor 1 Juni 2019

Halaman 145-168

http://journal.iaingorontalo.ac.id/index.php/ir

Rumus $\mathrm{H}_{0}: \rho=0$ tidak terdapat pengaruh antara Tunjangan Kinerja dan Motivasi dengan Kinerja Pegawai di IAIN Sultan Amai Gorontalo

Rumus $\mathrm{H}_{\mathrm{a}}: \rho \neq 0$ terdapat pengaruh antara Tunjangan Kinerja dan Motivasi dengan Kinerja Pegawai di IAIN Sultan Amai Gorontalo

Kaidah keputusan :

Jika nilai $F_{\text {hitung }}>F_{\text {tabel}}$, maka Ho ditolak dan Ha diterima, artinya koefisien regresi signifkan.

Jika nilai $\mathrm{F}_{\text {hitung }}<\mathrm{F}_{\text {tabel}}$, maka Ho diterima dan Ha ditolak, artinya koefisien regresi tidak signifikan.

\section{HASIL PENELITIAN DAN PEMBAHASAN}

\section{Hasil Penelitian}

IAIN Sultan Amai Gorontalo merupakan salah satu perguruan tinggi Islam yang ada di Gorontalo. Keberadaan IAIN sebagai satu satunya perguruan tinggi islam di gorontalo tentunya menjadi perguruan tinggi yang memiliki banyak peminat. IAIN Sultan Amai Gorontalo merupakan kelanjutan pendidikan menengah yang diselenggarakan untuk mempersiapkan peserta didik untuk menjadi anggota masyarakat yang memiliki kemampuan akademis dan profesional yang dapat menerapkan, mengembangkan dan menciptakan ilmu pengetahuan, teknologi dan kesenian.sebagai Perguruan tinggi yang cukup besar pastinya harus memiliki kualitas yang baik dimana para pegawai yang berada di Civitas Akademika juga memiliki kualitas yang baik pula. Berkualitas sumber daya manusia di IAIN Sultan Amai Gorontalo akan menarik minat calon mahasiswa. Karenanya, perguruan tinggi harus bisa memberikan pelayanan terbaik bagi mahasiswa maupun calon mahasiswa.

Populasi dalam penelitian ini adalah seluruh pegawai negeri sipil yang menerima tunjangan kinerja sebanyak 205 orang di Institut Agama Islam Negeri Gorontalo (IAIN) Sultan Amai Gorontalo. Pegawai Negeri Sipil IAIN Sultan Amai Gorontalo yang mendapatkan TUKIN sebagai berikut : Pegawai Struktural sebanyak 59 orang dan Dosen sebanyak 146 orang. Teknik pengambilan sampel pada penelitian ini yakni menggunakan teknik proporsional Random sampling. 


\section{Irfani}

ISSN 1907-0969 E ISSN 2442-8272

Volume 15 Nomor 1 Juni 2019

Halaman 145-168

http://journal.iaingorontalo.ac.id/index.php/ir

\section{A. Pengujian Persyaratan Analisis Data}

\section{Uji Validitas}

Uji Validitas digunakan untuk mengukur sah atau tidaknya suatu kuesioner. suatu item kuisioner dinyatakan valid apabila nilai $r_{\text {hitung }}>r_{\text {tabel }}$ Pengujian validitas dapat dilihat pada tabel 4.1 :

Tabel 1. Hasil Pengujian Validitas

\begin{tabular}{|c|c|c|c|c|}
\hline Variabel & $\begin{array}{l}\text { No. } \\
\text { Pernyataan }\end{array}$ & $\mathbf{r}_{\text {hitung }}$ & $\mathbf{r}$ tabel & Ket \\
\hline \multirow{15}{*}{$\begin{array}{l}\text { Tunjangan } \\
\text { Kinerja } \\
\left(\mathbf{X}_{1}\right)\end{array}$} & 1 & 0.876 & 0.244 & Valid \\
\hline & 2 & 0.719 & 0.244 & Valid \\
\hline & 3 & 0.876 & 0.244 & Valid \\
\hline & 4 & 0.484 & 0.244 & Valid \\
\hline & 5 & 0.484 & 0.244 & Valid \\
\hline & 6 & 0.422 & 0.244 & Valid \\
\hline & 7 & 0.876 & 0.244 & Valid \\
\hline & 8 & 0.876 & 0.244 & Valid \\
\hline & 9 & 0.876 & 0.244 & Valid \\
\hline & 10 & 0.369 & 0.244 & Valid \\
\hline & 11 & 0.411 & 0.244 & Valid \\
\hline & 12 & 0.308 & 0.244 & Valid \\
\hline & 13 & 0.498 & 0.244 & Valid \\
\hline & 14 & 0.294 & 0.244 & Valid \\
\hline & 15 & 0.876 & 0.244 & Valid \\
\hline
\end{tabular}




\section{Irfani}

ISSN 1907-0969 E ISSN 2442-8272

Volume 15 Nomor 1 Juni 2019

Halaman 145-168

http://journal.iaingorontalo.ac.id/index.php/ir

\begin{tabular}{|c|c|c|c|c|}
\hline Variabel & $\begin{array}{l}\text { No. } \\
\text { Pernyataan }\end{array}$ & $\mathbf{r}_{\text {hitung }}$ & $\mathbf{r}_{\text {tabel }}$ & Ket \\
\hline & 16 & 0.876 & 0.244 & Valid \\
\hline & 17 & 0.876 & 0.244 & Valid \\
\hline & 18 & 0.876 & 0.244 & Valid \\
\hline & 19 & 0.484 & 0.244 & Valid \\
\hline & 20 & 0.484 & 0.244 & Valid \\
\hline & 21 & 0.876 & 0.244 & Valid \\
\hline & 22 & 0.876 & 0.244 & Valid \\
\hline & 23 & 0.876 & 0.244 & Valid \\
\hline & 24 & 0.369 & 0.244 & Valid \\
\hline & 25 & 0.411 & 0.244 & Valid \\
\hline \multirow{8}{*}{$\begin{array}{l}\text { Motivasi } \\
\text { Kinerja } \\
\left(\mathbf{X}_{2}\right)\end{array}$} & 1 & 0.094 & 0.244 & Tidak Valid \\
\hline & 2 & 0.392 & 0.244 & Valid \\
\hline & 3 & 0.371 & 0.244 & Valid \\
\hline & 4 & 0.569 & 0.244 & Valid \\
\hline & 5 & 0.315 & 0.244 & Valid \\
\hline & 6 & 0.502 & 0.244 & Valid \\
\hline & 7 & 0.504 & 0.244 & Valid \\
\hline & 8 & 0.484 & 0.244 & Valid \\
\hline
\end{tabular}




\section{Irfani}

ISSN 1907-0969 E ISSN 2442-8272

Volume 15 Nomor 1 Juni 2019

Halaman 145-168

http://journal.iaingorontalo.ac.id/index.php/ir

\begin{tabular}{|c|c|c|c|c|}
\hline Variabel & $\begin{array}{l}\text { No. } \\
\text { Pernyataan }\end{array}$ & $\mathbf{r}_{\text {hitung }}$ & $\mathbf{r}_{\text {tabel }}$ & Ket \\
\hline & 9 & 0.433 & 0.244 & Valid \\
\hline & 10 & 0.314 & 0.244 & Valid \\
\hline & 11 & 0.532 & 0.244 & Valid \\
\hline & 12 & 0.385 & 0.244 & Valid \\
\hline & 13 & 0.411 & 0.244 & Valid \\
\hline & 14 & 0.350 & 0.244 & Valid \\
\hline & 15 & 0.474 & 0.244 & Valid \\
\hline & 16 & 0.038 & 0.244 & Tidak Valid \\
\hline & 17 & 0.167 & 0.244 & Tidak Valid \\
\hline & 18 & 0.553 & 0.244 & Valid \\
\hline & 19 & 0.101 & 0.244 & Tidak Valid \\
\hline & 20 & 0.072 & 0.244 & Tidak Valid \\
\hline & 21 & 0.403 & 0.244 & Valid \\
\hline & 22 & 0.417 & 0.244 & Valid \\
\hline & 23 & 0.350 & 0.244 & Valid \\
\hline & 24 & 0.403 & 0.244 & Valid \\
\hline & 25 & 0.351 & 0.244 & Valid \\
\hline & 26 & 0.311 & 0.244 & Valid \\
\hline & 27 & 0.378 & 0.244 & Valid \\
\hline
\end{tabular}




\section{Irfani}

ISSN 1907-0969 E ISSN 2442-8272

Volume 15 Nomor 1 Juni 2019

Halaman 145-168

http://journal.iaingorontalo.ac.id/index.php/ir

\begin{tabular}{|c|c|c|c|c|}
\hline Variabel & $\begin{array}{l}\text { No. } \\
\text { Pernyataan }\end{array}$ & $\mathbf{r}_{\text {hitung }}$ & $\mathbf{r}$ tabel & Ket \\
\hline & 28 & 0.657 & 0.244 & Valid \\
\hline & 29 & 0.019 & 0.244 & Tidak Valid \\
\hline & 30 & 0.141 & 0.244 & Tidak Valid \\
\hline & 31 & 0.392 & 0.244 & Valid \\
\hline & 32 & 0.342 & 0.244 & Valid \\
\hline & 33 & 0.392 & 0.244 & Valid \\
\hline & 34 & 0.160 & 0.244 & Tidak Valid \\
\hline \multirow{12}{*}{$\begin{array}{l}\text { Kinerja } \\
(\mathrm{Y})\end{array}$} & 1 & 0.854 & 0.244 & Valid \\
\hline & 2 & 0.648 & 0.244 & Valid \\
\hline & 3 & 0.181 & 0.244 & Tidak Valid \\
\hline & 4 & 0.491 & 0.244 & Valid \\
\hline & 5 & 0.854 & 0.244 & Valid \\
\hline & 6 & 0.110 & 0.244 & Tidak Valid \\
\hline & 7 & 0.279 & 0.244 & Valid \\
\hline & 8 & 0.278 & 0.244 & Valid \\
\hline & 9 & 0.136 & 0.244 & Tidak Valid \\
\hline & 10 & 0.854 & 0.244 & Valid \\
\hline & 11 & 0.515 & 0.244 & Valid \\
\hline & 12 & 0.576 & 0.244 & Valid \\
\hline
\end{tabular}


ISSN 1907-0969 E ISSN 2442-8272

Volume 15 Nomor 1 Juni 2019

Halaman 145-168

http://journal.iaingorontalo.ac.id/index.php/ir

\begin{tabular}{|c|c|c|c|c|}
\hline Variabel & $\begin{array}{l}\text { No. } \\
\text { Pernyataan }\end{array}$ & $\mathbf{r}_{\text {hitung }}$ & $\mathbf{r}$ tabel & Ket \\
\hline & 13 & 0.268 & 0.244 & Valid \\
\hline & 14 & 0.258 & 0.244 & Valid \\
\hline & 15 & 0.854 & 0.244 & Valid \\
\hline & 16 & 0.239 & 0.244 & Tidak Valid \\
\hline & 17 & 0.854 & 0.244 & Valid \\
\hline & 18 & 0.415 & 0.244 & Valid \\
\hline & 19 & 0.238 & 0.244 & Tidak Valid \\
\hline & 20 & 0.272 & 0.244 & Valid \\
\hline & 21 & 0.756 & 0.244 & Valid \\
\hline & 22 & 0.351 & 0.244 & Valid \\
\hline & 23 & 0.453 & 0.244 & Valid \\
\hline & 24 & 0.226 & 0.244 & Tidak Valid \\
\hline & 25 & 0.854 & 0.244 & Valid \\
\hline & 26 & 0.854 & 0.244 & Valid \\
\hline & 27 & 0.448 & 0.244 & Valid \\
\hline & 28 & 0.854 & 0.244 & Valid \\
\hline & 29 & 0.141 & 0.244 & Tidak Valid \\
\hline
\end{tabular}

Berdasarkan Tabel di atas terdapat 25 pernyataan untuk variable $\mathrm{X}_{1}$ (Tunjangan Kinerja), 34 pernyataan untuk variable $\mathrm{X}_{2}$ (Motivasi), terdapat 8 item pernyataan yang tidak valid yaitu item nomor $1,16,17,19,20,29,30,34$. Pernyataan untuk variable Y( Kinerja) 29 item pernyataan, terdapat 7 item pernyataan yang 


\section{Irfani}

ISSN 1907-0969 E ISSN 2442-8272

Volume 15 Nomor 1 Juni 2019

Halaman 145-168

http://journal.iaingorontalo.ac.id/i Reliability Statistics

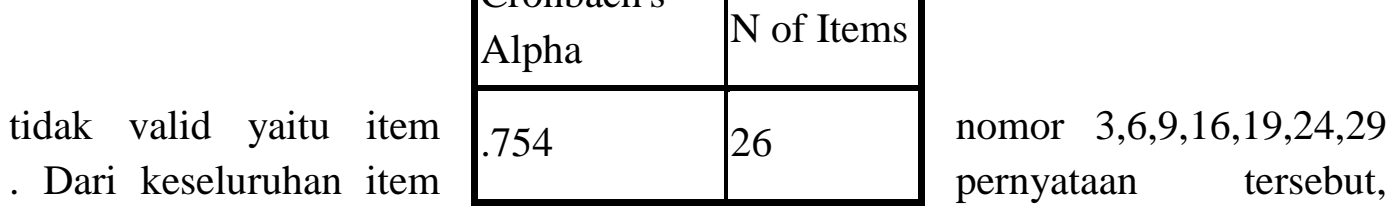
pernyataan yang valid yang dilanjutkan ke uji reabilitas.

\section{Reliabilitas}

Metode uji reliabilitas yang paling sering digunakan adalah Cronbach's Alpha. Suatu konstruk atau variabel dikatakan reliabel jika memberikan nilai Cronbach Alpha > 0,60. Hasil pengujian reliabilitas untuk semua variabel dapat dilihat pada tabel 4.2 :

\section{Tabel 2. ReliabilityStatistics $X_{1}$}

Berdasarkan hasil table out put tentang Reliability statistics variable Tunjangan Kinerja $\left(\mathrm{X}_{1}\right)$ didapat koefisien Alpha Cronbach yaitu sebesar 0,754. Hasil ini menunjukkan bahwa instrument tersebut reliabel karena $0.754>0.6$. Hasil uji reliabilitas pada tabel 4.2 di atas menunjukkan bahwa semua variabel sudah reliabel dan bisa di tunjukkan dengan nilai Cronbach Alpha diatas 0,6 sehingga dapat dikatakan semua konsep pengukur masing-masing variabel dari kuesioner adalah reliabel sehingga untuk selanjutnya item-item pada masingmasing konsep variabel tersebut layak digunakan sebagai alat ukur.

\section{Tabel 3. Reliability Statistics $X_{2}$}

Reliability Statistics
\begin{tabular}{|l|l|}
\hline $\begin{array}{l}\text { Cronbach's } \\
\text { Alpha }\end{array}$ & N of Items \\
\hline .704 & 27 \\
\hline
\end{tabular}

Berdasarkan hasil table out put tentang Reliability statistics variable Motivasi $\left(\mathrm{X}_{2}\right)$ didapat koefisien Alpha Cronbach yaitu sebesar 0,704. Hasil ini menunjukkan bahwa instrument tersebut reliabel karena $0.704>0.6$.

Tabel 4. Reliability Statistics (Y)

\section{Reliability Statistics}

\begin{tabular}{|l|l|}
\hline $\begin{array}{l}\text { Cronbach's } \\
\text { Alpha }\end{array}$ & N of Items \\
\hline .734 & 23 \\
\hline
\end{tabular}


ISSN 1907-0969 E ISSN 2442-8272

Volume 15 Nomor 1 Juni 2019

Halaman 145-168

http://journal.iaingorontalo.ac.id/index.php/ir

Berdasarkan hasil table out put tentang Reliability statistics variable Kinerja (Y) didapat koefisien Alpha Cronbach yaitu sebesar 0,734. Hasil ini menunjukkan bahwa instrument tersebut reliabel karena $0.734>0.6$

\section{Uji Regresi Berganda}

Untuk hasil analisis pengaruh antara variable Tunjangan Kinerja $\left(\mathrm{X}_{1}\right)$ dan Motivasi $\left(\mathrm{X}_{2}\right)$ terhadap Variabel Kinerja Pegawai (Y) sebagai berikut :

\section{Tabel 5}

\section{Coefficients $^{\mathrm{a}}$}

\begin{tabular}{|c|c|c|c|c|c|c|}
\hline \multirow{2}{*}{\multicolumn{2}{|c|}{ Model }} & \multicolumn{2}{|c|}{$\begin{array}{l}\text { Unstandardized } \\
\text { Coefficients }\end{array}$} & \multirow{2}{*}{\begin{tabular}{|l} 
Standardized \\
Coefficients
\end{tabular}} & \multirow[b]{2}{*}{$\mathrm{t}$} & \multirow[b]{2}{*}{ Sig. } \\
\hline & & B & Std. Error & & & \\
\hline \multirow[t]{3}{*}{1} & (Constant) & 17.754 & 7.368 & & 2.410 & .019 \\
\hline & TUKIN & .126 & .040 & .202 & 3.117 & .003 \\
\hline & $\begin{array}{l}\text { MOTIVAS } \\
\text { I }\end{array}$ & .886 & .074 & .777 & 11.982 & .000 \\
\hline
\end{tabular}

a. Dependent Variable: KINERJA

Berdasarkan tabel Coefficient di atas dapat digambarkan bahwa persamaan regresi dalam penelitian ini, yakni sebagai berikut: $Y=a+b_{1} X_{1+} b_{2} X_{2}=17.754+$ $0,126 \mathrm{X}_{1}+0,886 \mathrm{X}_{2}$.Konstanta sebesar 17.754 menyatakan jika tidak ada kenaikan nilai dari variabel penerapan sistem Tunjangan Kinerja (variabel $\mathrm{X}_{1}$ ), maka nilai Kinerja Pegawai (variabel Y) adalah 17.754.

Koefisien regresi variable Tunjangan Kinerja $\left(\mathrm{X}_{1}\right)$ sebesar 0,126 menyatakan bahwa setiap penambahan $1 \%$ nilai penerapan Tunjangan Kinerja akan memberikan peningkatan nilai Kinerja Pegawai (Y) sebesar 0,126.

Untuk koefisien regresi variable Motivasi $\left(\mathrm{X}_{2}\right)$ sebesar 0, 886 menyatakan bahwa setiap penambahan $1 \%$ nilai Motivasi $\left(\mathrm{X}_{2}\right)$ maka akan memberikan peningkatan nilai Kinerja Pegawai $(\mathrm{Y})$ sebesar 0, 886

\section{Pengujian Hipotesis}

\section{1)Pengujian kofisien regresi variable Tunjangan Kinerja $\left(X_{1}\right)$}

Berdasarkan tabel Coefficient di atas, pada kolom Unstandardized Coefficient, nilai $\mathrm{X}_{1}$ (Tunjangan Kinerja ) sebesar 3.117 tingkat signifikansi menggunakan $\alpha=0,05 \%$ dan tabel distribusi t dicari pada $\alpha=0,05: 2$ derajat 


\section{Irfani}

ISSN 1907-0969 E ISSN 2442-8272

Volume 15 Nomor 1 Juni 2019

Halaman 145-168

http://journal.iaingorontalo.ac.id/index.php/ir

kebebasan $(\mathrm{dk}) \mathrm{n}-\mathrm{k}-1=67-2-1=64$ dan $\alpha=0.05$, dalam rumus $(\mathrm{t}$ tabel $=\mathrm{t}(\alpha / 2 ;$ $\mathrm{n}-\mathrm{k}-1)$ atau $(\mathrm{t}$ tabel $=\mathrm{t}(0.05 / 2 ;(67-2-1)=0.025 ; 64)$ sehingga diperoleh nilai $\mathrm{t}_{\text {tabel }}=1,980$. nilai $\mathrm{t}_{\text {hitung }}>\mathrm{t}_{\text {tabel }}$ atau $3.117>1,980$, maka $\mathrm{H}_{0}$ ditolak dan $\mathrm{Ha}$ diterima, yang berarti koefisen regresi berpengaruh secara signifikan.

\section{Pengujian koefisien regresi variable Motivasi $\left(\mathbf{X}_{2}\right)$}

Berdasarkan tabel Coefficient di atas, pada kolom Unstandardized Coefficient, nilai $\mathrm{X}_{2}$ (Motivasi ) sebesar 11.982 tingkat signifikansi menggunakan $\alpha=0,05 \%$ dan tabel distribusi t dicari pada $\alpha=0,05: 2$ derajat kebebasan (dk) n-k$1=67-2-1=64$ dan $\alpha=0.05$, dalam rumus $(\mathrm{t}$ tabel $=\mathrm{t}(\alpha / 2 ; \mathrm{n}-\mathrm{k}-1)$ atau $(\mathrm{t}$ tabel $=\mathrm{t}(0.05 / 2 ;(67-2-1)=0.025 ; 64)$ sehingga diperoleh nilai $\mathrm{t}_{\text {tabel }}=1,980$. nilai $\mathrm{t}_{\text {hitung }}>\mathrm{t}_{\text {tabel }}$ atau $11.982>1,980$, maka $\mathrm{H}_{0}$ ditolak dan Ha diterima, yang berarti koefisen regresi berpengaruh secara signifikan.

\section{Uji Koefisien regresi secara bersama - sama}

Hasil output analisis regresi diketahui nilai $\mathrm{F}$ adalah sebagai berikut :

\section{Tabel.6}

\section{Uji F}

\section{ANOVA $^{\text {b }}$}

\begin{tabular}{|c|c|c|c|c|c|c|}
\hline \multicolumn{2}{|c|}{ Model } & \multicolumn{2}{|c|}{$\mid \begin{array}{ll}\text { Sum } & \text { of } \\
\text { Squares }\end{array}$} & Mean Square & $\mathrm{F}$ & Sig. \\
\hline 1 & Regression & 2452.338 & 2 & 1226.169 & 117.453 & $.000^{\mathrm{a}}$ \\
\hline & Residual & 668.139 & 64 & 10.440 & & \\
\hline & Total & 3120.478 & 66 & & & \\
\hline
\end{tabular}

a. Predictors: (Constant), MOTIVASI,

\section{TUKIN}

b. Dependent Variable: KINERJA

Berdasarkan Tabel ANOVA diatas diperoleh $F_{\text {hitung }}$ sebesar 117.453 Pada tabel ANOVA yang telah diperoleh dengan menggunakan SPSS 16.0 dapat dilihat nilai Signifikansi sebesar 0.000. Nilai Signifikansi ini lebih kecil dari nilai $\alpha$ yaitu 0.05 artinya bahwa kita menolak $\mathrm{H}_{0}$ berarti bahwa persamaan garis regresinya linear. Berdasarkan tabel $\mathrm{ANOVA}^{\mathrm{b}}$ atau uji $\mathrm{F}$, ternyata didapat $\mathrm{F}_{\text {hitung }}$ adalah 117.453 dengan tingkat signifikan $0,000^{\mathrm{a}}$ atau 0 . Karena probabilitas 


\section{Irfani}

ISSN 1907-0969 E ISSN 2442-8272

Volume 15 Nomor 1 Juni 2019

Halaman 145-168

http://journal.iaingorontalo.ac.id/index.php/ir

$(0,000)$ jauh lebih kecil dari 0,05 , sehingga model regresi dapat dipakai untuk memprediksi kualiats pelayanan (Variabel Y).

\section{Hasil Pembahasan}

IAIN Sultan Amai Gorontalo merupakan salah satu perguruan tinggi Islam yang ada di Gorontalo. Keberadaan IAIN sebagai satu satunya perguruan tinggi islam di gorontalo tentunya menjadi perguruan tinggi yang memiliki banyak peminat. IAIN Sultan Amai Gorontalo merupakan kelanjutan pendidikan menengah yang diselenggarakan untuk mempersiapkan peserta didik untuk menjadi anggota masyarakat yang memiliki kemampuan akademis dan profesional yang dapat menerapkan, mengembangkan dan menciptakan ilmu pengetahuan, teknologi dan kesenian.sebagai Perguruan tinggi yang cukup besar pastinya harus memiliki kualitas yang baik dimana para pegawai yang berada di Civitas Akademika juga memiliki kualitas yang baik pula. Berkualitas sumber daya manusia di IAIN Sultan Amai Gorontalo akan menarik minat calon mahasiswa. Karenanya, perguruan tinggi harus bisa memberikan pelayanan terbaik bagi mahasiswa maupun calon mahasiswa.

Merujuk dari hasil hipotesis yang diajukan dalam penelitian ini menunjukan bahwa tunjangan kinerja dan motivasi memiliki hubungan keterikatan yang sangat erat dengan kinerja pegawai di IAIN Sultan Amai Gorontalo. Hal ini membuktikan bahwa semakin baik tunjangan kinerja dan motivasi maka semakin baik pula kinerja pegawai. Berdasarkan hasil hipotesis ini ,menunjukan tunjangan kinerja dan motivasi berpengaruh terhadap kinerja pegawai , "Diterima". Dimana dari hasil perhitungan diperoleh $\mathrm{T}_{\text {hitung }}>\mathrm{T}_{\text {tabel }}$ yaitu $117.453>1,980$, maka $\mathrm{H}_{0}$ ditolak dan Ha diterima, dengan demikian berarti tunjangan kinerja dan motivasi berpengaruh terhadap kinerja pegawai.

Berdasarkan hasil yang diperoleh pada penelitian ini, pada indicator kuantitas hasil kerja yang dicapai adalah dilihat dari jumlah kerja yang dikerjakan oleh seorang pegawai dengan penggunaan waktu. Kuantitas kinerja merupakan hasil output berupa jumlah dokumen, konsep, naskah, surat keputusan, laporan dan lain-lain yang dihasilkan oleh setiap pegawai yang didasarkan tugas serta jabatannya. Kuantitas kinerja pegawai di IAIN Sultan Amai Gorontalo berdasarkan sasaran kinerja pegawai atau SKP serta laporan kinerja harian (LKH) disesuaikan dengan dokumen hasil kerja yang merupakan bukti bahwa pegawai 


\section{Irfani}

ISSN 1907-0969 E ISSN 2442-8272

Volume 15 Nomor 1 Juni 2019

Halaman 145-168

http://journal.iaingorontalo.ac.id/index.php/ir

bekerja sesuai dengan harapan dan target yang ditetapkan. Ketercapaian target kinerja tersebut sangat mempengaruh besaran pemberian tunjangan kinerja.

Pada indikator kualitas hasil kerja diperoleh penilaian yaitu menjaga mutu kerja dengan tidak atau jarang melakukan kesalahan. Berdasarkan sasaran kinerja pegawai peningkatan terhadap mutu atau kualitas kinerja pegawai meningkat yaitu dari rata-rata 80 meningkat ke 85.dari penilaian tersebut maka kinerja pegawai dari indikator kualitas dikategorikan baik. Hal ini dapat dilihat pemberian pelayanan dan mutu kerja pegawai sesuai dengan standar yang ditetapkan. Dari penelitian yang dilakukan, peningkatan kualitas dibuktikan dengan penilaian perilaku kerja pegawai.

Pada indikator ketepatan waktu, pengukuran pada indikator ini adalah terhadap jangka waktu pencapaian hasil kerja yaitu mengacu pada penyelesaian tugas dalam waktu yang ditentukan (cepat atau lambat). Dengan adanya SKP, jangka waktu pegawai dalam mencapai kerja dapat terukur. Kinerja pegawai dalam menyelesaikan tugas cukup baik yang dapat dilihat pada waktu pelaksanaan tugas pegawai. Hal ini dapat dibuktikan dengan ketepatan waktu pelaksanaan tugas pegawai sesuai dengan standar kemampuan rata-rata penyelesaian setiap beban kerja yag dimiliki masing-masing pegawai.

\section{KESIMPULAN}

Berdasarkan hasil penelitian dan pembahasan yang diuraikan pada bab sebelumnya, maka dapat ditarik kesimpulan sebagai berikut :

1. Tunjangan kinerja berpengaruh terhadap kinerja Pegawai Negeri Sipil IAIN Sultan Amai Gorontalo. Hal ini berarti semakin meningkat tunjangan kinerja memacu kerja pegawai dalam melaksanakan pekerjaan setiap hari dan akan menghasilkan kinerja yang optimal.

2. Motivasi berpengaruh positif terhadap kinerja pegawai IAIN Sultan Amai Gorontalo. Hal ini menunjukkan bahwa semakin tinggi motivasi Pegawai Negeri Sipil IAIN Sultan Amai Gorontalo dalam melakukan pekerjaan maka kinerja pegawai akan meningkat.

3. Secara simultan atau bersama-sama tunjangan kinerja dan motivasi berpengaruh positif terhadap kinerja Pegawai Negeri Sipil IAIN Sultan Amai Gorontalo. 


\section{Irfani}

ISSN 1907-0969 E ISSN 2442-8272

Volume 15 Nomor 1 Juni 2019

Halaman 145-168

http://journal.iaingorontalo.ac.id/index.php/ir

\section{DAFTAR PUSTAKA}

Herson Anwar dan Lian G. Otaya,Statistika Pendidikan "Teori Dan Aplikas, Cet.1.Gorontalo: Sultan Amai Press:2015.

Jane Christin, Djudi Mukzam, pengaruh Motivasi Internal dan kesternal Terhadap Kinerja Karyawan, (Studi Kasus Pada Karyawan PT Indomarco Prismatama Distribution Centre Bogor, Jurnal Administrasi Bisnis (JAB) Vol.50 No 5 September 2017.

Kompri,Motivasi Pembelajaran Perspektif Guru Dan Siswa.Bandung:PT Remaja Rosdakarya Offset,2015.

Liza Hardani (Balai Karantina Pertanian Kelas I Banjarmasin) Ahmad Alim Bachri (Universitas Lambung Mangkurat Banjarmasin) Dahniar (Universitas Lambung Mangkurat Banjarmasin Jurnal Wawasan Manajemen, Vol. 4, Nomor 1, Februari 2016.

Maya Andriani, Kristiana Wididawati, Penerapan Motivasi Karyawan Menurut Teori Dua Faktor Frederick Harzberg Pada PT Aristika Kreasi Mandiri, Jurnal Administrasi Kantor Vol. 5 No 1 Juni 2017.

Pilatus Deikme, Motivasi Kerja Dan Budaya Organisasi Pengaruhnya Terhadap Kinerja Pegawai Bagian Keuangan Sekda Kabupaten Mimika provinsi Papua, Jurnal EMBA col.1 No 3 Juni 2013.

Peraturan Menteri Agama nomor 29 tahun 2016 tentang pedoman pelaksanaan Pemberian tunjangan kinerja bagi pegawai negeri sipil.

Robbins Stephen P, Perilaku Organisasi .Jakarta :PT Indeks kelompok Gramedi,2006.

Sardiman, Interaksi Dan Motivasi Belajar.Jakarta: Rajawali Pers, 2011.

Tika, P. Budaya Organisasi Dan Peningkatan Kinerja Perusahaan. PT Bumi Aksara. Jakarta 2006.

Uhar Suharputra, Metode Penelitian Kuantiitatif,Kualitatif dan tindakan .Bandung: PT Refika Aditama,2012.

Undang-undang Aparatur Sipil Negara No 5 Tahun 2015 Tentang Tunjangan Kinerja.

Yusnia Hanifah Jurnal Bisnis dan Manajemen Vol. 11, No. 2 Mei 2017 , Pengaruh Tunjangan Kinerja Terhadap Motivasi Kerja, Disiplin Kerja Dan Kinerja Pegawai Balai Pengelolaan Daerah Aliran Sungai Di Jawa Timur 